NASA Technical Memorandum 100957

AIAA-88-3300

\title{
Catalytic Ignition of Hydrogen and Oxygen Propellants
}

Robert L. Zurawski

Lewis Research Center

Cleveland, Ohio

and

James M. Green

Sverdrup Technology, Inc.

NASA Lewis Research Center Group

Cleveland, Ohio

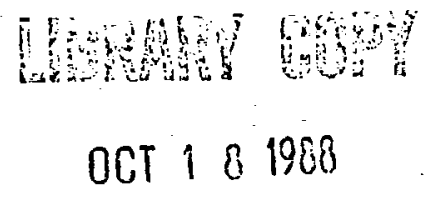

LANGLEY RESEARCH CENTER

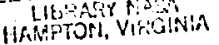

Prepared for the

24th Joint Propulsion Conference

cosponsored by the AIAA, ASME, SAE, and ASEE

Boston, Massachusetts, July 11-13, 1988 


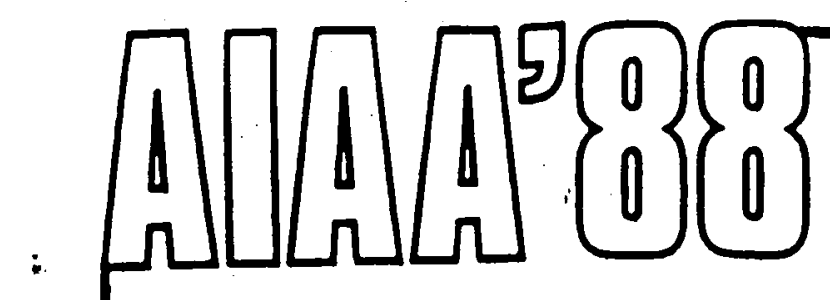

AIAA-88-3300

Catalytic Ignition of Hydrogen and Oxygen Propellants

Robert L. Zurawski, NASA Lewis

Research Center, Cleveland, $\mathrm{OH}$; and

James M. Green, Sverdrup Technology,

Inc., NASA Lewis Research Center Group,

Cleveland, $\mathrm{OH}$

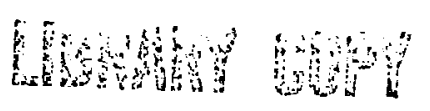 \\ OCT 181988 \\ LANGLEY RESEARCH CENTER \\ HAMTION, VIFGINIA \\ AIAA/ASME/SAE/ASEE 24th JOINT PROPULSION CONFERENCE JULY 11-13, 1988/Boston, Massachusetts}




\title{
CATALYTIC IGNITION OF HYDROGEN AND OXYGEN PROPELLANTS
}

\author{
Robert L. Zurawski \\ National Aeronautics and Space Administration \\ Lewis Research Center \\ Cleveland, Ohio 44135 \\ and \\ James M. Green \\ Sverdrup Technology, Inc. \\ NASA Lewis Research Center Group \\ Cleveland, Ohio 44135
}

\section{SUMMARY}

An experimental program was conducted to evaluate the catalytic ignition of gaseous hydrogen and oxygen propellants. Shell 405 granular catalyst and a monolithic sponge catalyst were tested. Mixture ratio, mass flow rate, propellant temperature, and back pressure were varied parametrically in testing to determine the operational limits of the catalytic igniter. The test results show that the gaseous hydrogen and oxygen propellant combination can be ignited catalytically using Shell 405 catalyst over a wide range of mixture ratios, mass flow rates, and propellant injection temperatures. These operating conditions must be optimized to ensure reliable ignition for an extended period of time. A cyclic life of nearly $2000,2-s e c$ pulses at nominal operating conditions was demonstrated with the catalytic igniter. The results of the experimental program and the established operational limits for a catalytic igniter using the Shell 405 catalyst are presented.

\section{INTRODUCTION}

The hydrogen/oxygen propellant combination is commonly used for space propulsion systems because of its high specific impulse, fast reaction rate, lack of toxicity, and excellent regenerative cooling capability. However, this bipropellant combination is not hypergolic. Ignition of 1 iquid propellant rocket engines fueled by hydrogen and oxygen must be accomplished by an igniter device which releases heat and initlates reaction of the main propeliants. $A$ number of ignition techniques have been investigated for liquid propellant rocket engines and combustion devices with varying degrees of success. These ignition techniques have included; pyrotechnic, hypergolic, electric, hot-gas tapoff, ionic, passive thermal, dynamic thermal, and catalytic ignition (ref. 1). Catalytic ignition is a promising technique and has several potential advantages compared to the other ignition techniques. This report presents the results of an experimental program conducted to investigate the operational characteristics of a catalytic igniter for the gaseous hydrogen and oxygen propellant combination.

Catalytic ignition is a simple concept which has flown in space for time periods over 8 years, performing thousands of qualified cycles with monopropellant hydrazine. Catalytic igniters have a minimum component count which makes them simple, safe, lightweight, and inexpensive. The simplicity of the concept is demonstrated by the fact that it requires no external energy source. In 
addition, catalytic igniters are passive in operation and present no radio frequency interference problems. These attributes make catalytic ignition competitive with conventional igniters such as the spark torch and hypergolic system for use in liquid bipropellant rocket engines.

The feasibility of using catalysts to promote the reaction of hydrogen and oxygen was demonstrated in several research programs in the 1960's and early 1970's. Early investigations by the NASA Lewis Research Center (ref. 2) studying catalytic ignition identified several granular catalysts such as Shell 405 and Englehard MFSA that are reactive with hydrogen and oxygen. Shell 405 uses an iridium catalyst agent on a porous aluminum oxide substrate. Shell 405, which is very effective for the decomposition of monopropel lant hydrazine (ref. 3), became a preferred catalyst for the ignition of hydrogen and oxygen. An extensive experimental data base was created for catalytic ignition of hydrogen and oxygen propellants using Shell 405 catalyst (ref. 4). However, the longevity and reliability required for a catalytic igniter to be competitive with spark torch igniters for use with hydrogen and oxygen propellants was not demonstrated.

Granular catalysts such as Shell 405 possess a high specific surface area of metal but also have shortcomings for catalytic ignition of hydrogen and oxygen propellants. These include the inherently high pressure drop of a tightly packed granular catalyst bed and the attrition due to thermal and mechanical loads on the catalyst particles. Monolithic catalysts are unitary structures which offer the potential advantages of very low pressure drop, attrition resistance for longer life and design flexibility. The NASA Ames Research Center investigated monolithic catalyst beds for hydrazine reactors in the early. 1970's and demonstrated a monolithic catalyst with activity and performance comparable to Shell 405 catalyst (ref. 5). A monolithic sponge catalyst was tested in addition to the Shell 405 granular catalyst in the present program to explore these potential benefits with hydrogen and oxygen. The monoiithic catalyst consisted of a carbon sponge substrate coated with rhenium to give it structural integrity and iridium as the catalyst agent.

The goal of the present experimental program was to build on the established experimental data base for catalytic ignition, exploring areas such as low temperature ignition, monolithic catalyst beds, and propeliant injection techniques, and to improve the life and reliability of the catalytic igniter. Catalytic igniter hardware was designed using generalized design guideilines and scaling criteria for catalytic igniters that were developed through analysis of experimental data from reference 4 . A facility was constructed to test the catalytic igniter under space-simulated conditions. Finally, testing was conducted to establish the operational limits of the catalytic igniter over a wide range of operating conditions.

In this report the results of the experimental program are presented. The catalytic igniter test hardware, test facility, and test procedures are described. The igniter operational characteristics for both the granular Shell 405 catalyst and monolithic sponge catalyst are discussed. Finally, the results of tests to characterize the performance, reliability, and life of the catalytic igniter using the Shell 405 granular catalyst are presented. 


\section{APPARATUS}

Test Hardware

A schematic of the catalytic igniter assembly is shown in figure 1. The hardware consists of an upstream injector, spool plece, downstream injector, and nozzle. The reactor of the catalytic igniter is contained in the spool piece and contains a mixing chamber (to enhance mixing of the hydrogen and oxygen) and the catalyst bed. Both of the injector units are made of type 304 stainless steel, while the spool piece and nozzle are made of Hastelloy $X$. Hydrogen gas and the primary oxygen gas are introduced into the reactor by means of a cross-drilled injection scheme in the upstream injector. The hydrogen gas flows axially from the fuel inlet into the reactor through twelve $0.081-\mathrm{cm}(0.032-i n$.$) diameter injector holes. The oxygen gas flows from the$ oxidizer inlet in through the annulus of the injector into $0.157-\mathrm{cm}(0.062-\mathrm{in}$. diameter holes that intersect with the nine $0.053-\mathrm{cm}(0.021-\mathrm{in}$.) oxygen orifices, and then flows axially into the reactor. Figure 2 shows a schematic. of both the upstream and downstream injectors. The oxygen inlet is isolated from the catalyst bed and from the outside using rubber O-ring seals. The upstream injector is connected to the spool piece with bolts that pass through compression springs. With these springs in place, the upper injection faceplate keeps the catalyst bed under constant compression so that the catalyst remains tightly packed if it attrits. The reactor has a chamber diameter of $1.270 \mathrm{~cm}$ $(0.500 \mathrm{in.})$ and a nominal length of $5.080 \mathrm{~cm}(2.000 \mathrm{in.})$.

The hydrogen and primary oxygen are injected into a mixing chamber where the gases are premixed, flow through the catalyst bed where they ignite, and then flow through the downstream injector into the nozzle. The nozzle has a throat diameter of $0.508 \mathrm{~cm}(0.200 \mathrm{in}$.$) and an exit diameter of 1.270 \mathrm{~cm}$ ( $0.500 \mathrm{in.}$. . This geometry yields a value of 6.25 for both the contraction and expansion ratios. The mixing chamber is $1.270 \mathrm{~cm}(0.500 \mathrm{in.})$ long and consists of an inert material separated from the catalyst bed by a stainless steel screen. The catalyst bed is nominally $3.810 \mathrm{~cm}(1.500 \mathrm{in.})$ long.

Downstream oxygen injection increases igniter life by allowing the catalyst to operate at lower temperatures and mixture ratios than a design where all the oxygen is passed through the catalyst bed. The downstream injector uses a cross-drllled injection scheme. The combustion gases from the catalyst bed pass axially through twelve $0.102-\mathrm{cm}(0.040-$ in.) orifices into the downstream chamber. The secondary oxygen enters from the annulus through nine $0.064-\mathrm{cm}(0.025-i n$.$) diameter orifices. The hardware can thus be operated$ with a low mixture ratio in the catalyst bed and a higher mixture ratio in the downstream chamber. Figure 3 shows an exploded view of the catalytic igniter hardware.

Two different catalyst materials were tested, along with a number of different mixing chamber materials. The majority of the testing was done with 14 to 18 mesh Shell 405 catalyst, which consists of iridium catalyst on an aluminum oxide (alumina) substrate. Specifications for the Shell 405 catalyst are given in table I. A monolithic catalyst was also tested, which consists of a carbon sponge substrate with rhenium deposited on the carbon for strength using chemical vapor deposition (CVD). The active metal, iridium, was then deposited on the sponge using CVD. Characteristics of the monolithic sponge catalyst are given in table II. The mixing chamber materials tested were silica sand, fused zirconia/silica, zirconia/magnesium, $0.238 \mathrm{~cm}(0.094 \mathrm{in.})$ diameter, high carbon 
chrome steel balls, and $0.238 \mathrm{~cm}(0.094 \mathrm{in.})$ diameter 440 stainless steel balls. Figure 4 shows the Shell 405 catalyst and some of the mixing chamber materials tested. Figure 5 shows the monolithic sponge catalyst.

Temperature measurements were taken inside the catalyst bed and on the backwall at the locations shown in flgure 1. The backwall thermocouples were used for diagnostic purposes and to collect heat transfer data from the igniter. Type K (chromel constantan) thermocouples were used for the temperature measurements. The bed thermocouples were labeled T1, T2, T3, and T4, with $\mathrm{Tl}$ located nearest the upstream injector in the mixing chamber and T4 farthest downstream in the catalyst bed. These thermocouples were located at the inner radius of the reactor. Pressure measurements were taken inside the catalyst bed (IPC) and in the downstream injector (PC) using strain gauge type pressure transducers. The pressure transducers for these measurements were located just downstream of the primary and secondary injectors, respectively.

\section{Test Facility}

Testing of the catalytic igniters was conducted in the Combustion Research Laboratories at NASA Lewis. The test facility, which was designed and bullt for the testing of ignition systems and small gaseous hydrogen/oxygen rockets (up to 50 lbf thrust), is capable of testing at sea level or space simulated altitude, with ambient or chilled propellants. Figure 6 shows a photograph of the test stand in the test facility.

A schematic of the propellant feed system for the test facllity is shown in figure 7. The feed system consists of two gaseous oxygen feed lines and one gaseous hydrogen feed line. Each oxygen line can deliver a maximum mass flow rate of $0.050 \mathrm{~kg} / \mathrm{sec}(0.110 \mathrm{lb} / \mathrm{sec})$, and the hydrogen line can deliver a maximum flow rate of $0.012 \mathrm{~kg} / \mathrm{sec}(0.026 \mathrm{lb} / \mathrm{sec})$. Sonic orifices are used to control the mass flow rates in all propellant lines. These orifices deliver a constant mass flow rate under choked flow conditions. The mass flow rate is based on the upstream temperature and pressure of the propellant. The upstream pressure is regulated while the upstream temperature is amblent. Different diameter orifices can be installed in the feed lines to deliver the mass flow rates necessary for testing. A gaseous nitrogen system purges all the propellant lines and the vacuum chamber. Propellants and gaseous nitrogen are delivered from remote $16.55 \mathrm{MN} / \mathrm{m}^{2}$ (2400 psig) trailers.

The altitude system consists of a $0.61 \mathrm{~m}(2.0 \mathrm{ft})$ diameter, $1.22 \mathrm{~m}$ $(4.0 \mathrm{ft})$ long vacuum chamber driven by a two stage ejector system mounted on the roof of the test cell. The vacuum chamber is mounted on tracks for easy removal for hardware access or sea level testing. The ejectors consume $3.63 \mathrm{~kg} / \mathrm{sec}(8.0 \mathrm{lb} / \mathrm{sec})$ of combustion air to draw a vacuum of less than $0.0017 \mathrm{MN} / \mathrm{m}^{2}(0.25 \mathrm{psia})$ in the chamber.

The propellant inlet temperature to the igniter is controlled by passing the gaseous propellant through a bolling liquid nitrogen heat exchanger. The propellant lines are colled inside the heat exchanger to provide more surface area for heat transfer. A partition separates the fuel and oxidizer colls in the heat exchanger as a safety precaution. Liquid nitrogen is fed from a remotely located dewar into the compartments of the heat exchanger. The level of liquid nitrogen in the heat exchanger is automatically controlled by level 
sensing devices that enable more liquid nitrogen to be added automatically when the level is too low.

The control system in the cell consists of both manual and automatic control. A programmable control system is used to open and close valves during the run based on manually entered timing values. Automatic and manual aborts are available if a problem should occur during testing.

The test cell has both high-speed and low-speed data acquisition systems. The high-speed data acquisition system records 100 readings/sec, averages every 10 readings, and outputs a data point every $1 / 10 \mathrm{sec}$. A high-speed data program on the mainframe computer performs calculations with the raw data." A minicomputer and a strip chart recorder are used to monitor the factlity and obtain local, immediate data acquisition during testing.

\section{Test Procedure}

Pulse mode testing, which simulates the repeated use of the igniter.with a reusable engine, was conducted with the catalytic igniter. Each hot fire pulse was 2 or $3 \mathrm{sec}$ in duration, preceded by a hydrogen lead to ensure smooth start-up and followed by a hydrogen lag to insure smooth shut-down. The catalyst bed was then purged with nitrogen gas to remove all of the residual propellants. New catalyst beds were conditioned by flowing hydrogen through the bed for approximately 1 min prior to the test. This hydrogen purge activated the catalyst bed by removing residual oxygen adsorbed on the surface.

Catalytic igniter tests were conducted over a wide range of operating conditions. The mixture ratio (ratio of oxidizer to fuel) in the catalyst bed was varied from 0.3 to 1.2 , with the nominal operating value being 1.0 . The total mass flow rate through the bed was varied from 0.0009 to $0.0027 \mathrm{~kg} / \mathrm{sec}$ $(0.002$ to $0.006 \mathrm{lb} / \mathrm{sec})$, with $0.0018 \mathrm{~kg} / \mathrm{sec}(0.004 \mathrm{lb} / \mathrm{sec})$ being the nominal operating value. When downstream oxygen injection was employed, the overall mixture ratio was varied from 2.0 to 12.0 and the overall mass flow rate was varied from 0.0027 to $0.0215 \mathrm{~kg} / \mathrm{sec}(0.006$ to $0.0473 \mathrm{lb} / \mathrm{sec})$. The initial temperature of the catalyst bed was varied from ambient temperatures to $-164.3{ }^{\circ} \mathrm{C}$ $\left(-263.7^{\circ} \mathrm{F}\right)$. Testing was done at ambient back pressure (sea-level) as well as

under a vacuum. The testing presented in the Results and Discussion section of this report was conducted with 14 to 18 mesh Shell 405 catalyst, with the exception of the monolithic catalyst testing.

\section{RESULTS AND DISCUSSION}

\section{Igniter Operational Characteristics}

The igniter was initially characterized without downstream injection in order to protect the nozzle from the high temperatures resulting when downstream oxygen injection was employed. For these cases, the mixture ratio in the catalyst bed was;

$$
\left(\frac{O}{F}\right)_{b}=\frac{W_{o a}}{W_{f a}}
$$


where

$(0 / F)_{b}$ catalyst bed mixture ratio

Woa primary oxygen mass flow rate, $\mathrm{kg} / \mathrm{sec}$

$\mathrm{W}_{\mathrm{fa}} \quad$ hydrogen mass flow rate, $\mathrm{kg} / \mathrm{sec}$

Several tests were inftially conducted in the program with only Shell 405 catalyst in the reactor. The inefficient mixing of the primary injector resulted in damaging hot spots in the catalyst bed. The hot spots were due to axial injection of a nonuniform mixture of hydrogen and oxygen into the catalyst bed. These tests emphasize the criticality of the propellant injection conditions to the operation of the catalytic igniter. A high efficiency primary injector which can deliver a uniform mixture of hydrogen and oxygen to the catalyst bed is essential to extended, reliable operation of the catalytic igniter. In subsequent tests a mixing chamber was placed downstream of the primary injector to premix the propeliants prior to their injection into the catalyst bed.

Screening tests were conducted to evaluate varlous mixing chamber materials for use in the reactor. The materials tested were silica sand, fused zirconia/silica, fused zirconia/magnesium, high carbon chrome steel balls, and 440 stainless steel balls. Both types of steel balls were able to withstand the high-pressure, high-velocity gases and thermal shock inside the reactor, while the other materials quickly deteriorated to varying degrees with use. This deterioration increased the pressure drop across the reactor with time and also adversely affected the flow characteristics and mixing efficiency of the diffusion bed. Flame flashback into the mixing chamber occurred frequently. The steel balls did not deteriorate with time as did the other materials, but they exhibited localized melting and fusion if a flashback occurred. This was more of a problem with the carbon steel balls than with the stainless steel balls. Consequently, $0.238 \mathrm{~cm}(0.094 \mathrm{in.})$ diameter 440 stainless steel balis were selected for use in the mixing chamber. The stainless steel balls provided adequate propellant mixing to prevent damaging hot spots in the catalyst bed.

Tests were next conducted to select a nominal mass flow rate through the catalyst bed. The mass flow rate through the reactor affects the pressure drop and the external particle mass and heat transfer resistances, which influence conversion in the reactor. The pressure drop through the catalyst bed and temperature were measured as a function of reactor total mass flow rate. The results of these tests are shown in figures 8 and 9 , respectively. A nominal mass flow rate of $0.0018 \mathrm{~kg} / \mathrm{sec}(0.004 \mathrm{lb} / \mathrm{sec})$ was chosen to maintain a reasonable pressure drop through the reactor as shown in figure 8 . Also, reactor temperature is roughly constant at mass flow rates above $0.0018 \mathrm{~kg} / \mathrm{sec}$ $(0.004 \mathrm{lb} / \mathrm{sec})$, suggesting that external particle heat and mass transfer resistances are minimal beyond this point. It should be noted that granular catalyst type, catalyst particle size (which largely affects the internal heat and mass transfer resistances), and catalyst bed volume were not varied during the test program. Results reported here could change if the catalyst metal loading, type of catalyst, or the catalyst particle size were changed. 
A phenomena which critically affects the operation of the igniter is flashback. Flashback is the sudden propagation of the flame in the upstream direction from the catalyst bed into the mixing chamber or to the injector. This phenomenon can severely damage the mixing chamber and injector and adversely affects the performance of the igniter. Figure 9 shows no incidents of flashback on any of the test firings (flashback would be detected by large rises in temperature at $\mathrm{Tl}$ and $\mathrm{T} 2$ ). However, early testing indicated that flashback may occur for mass flow rates lower than $0.0016 \mathrm{~kg} / \mathrm{sec}$ $(0.0035 \mathrm{lb} / \mathrm{sec})$.

The hardware used in this test program would not permit a thorough study of the flashback phenomena. The hardware employed a showerhead type injector for both the fuel and oxidizer such that the propellants were injected axially in discrete streams. This led to regions of nonuniform mixture ratio in the reactor. A mixing chamber was therefore necessary to enhance mixing of the propellants. However, melting and fusion of the mixing chamber materlal with flashback altered the flow characteristics in the reactor, which made the study of the flashback phenomena difficult. A more efficient injector (a premixing type injector with a large number of elements per unit area, for example) that supplies a uniform mixture of hydrogen and oxygen to the catalyst bed would substantially improve the performance of the igniter and make flashback predictable as a function of the flow conditions in the reactor. While the flashback phenomena was not thoroughly studied in this program, the effects of variations in flow velocity, mixture ratio, and igniter internal geometry on igniter flashback characteristics have been characterized in the past (ref. 4).

Testing was next conducted to determine a nominal mixture ratio for the reactor. This operating mixture ratio should be high enough for ignition, while remaining low enough to prolong the life of the catalyst bed. Figure 10 shows the effect of mixture ratio on the temperature distribution at the end of a 3-sec firing. Based on this data, a nominal mixture ratio of 1.0 was chosen. Operating at reactor temperatures above $648.9^{\circ} \mathrm{C}\left(1200^{\circ} \mathrm{F}\right.$ ) (a mixture ratio of 1.0) limits the life of the catalyst bed. Tl, which was located in the mixing chamber, remained at ambient temperature, indicating that flashback did not occur. T2 increased only slightly due to axial conduction, while T3 and T4 increased linearly with mixture ratio.

Throughout the course of testing it was observed that the location of the flame front changed due to a variety of factors. Notice in a comparison of figures 9 and 10 at the same operating conditions (mixture ratio $=1.0$ and mass flow rate $=0.0018 \mathrm{~kg} / \mathrm{sec}(0.004 \mathrm{lb} / \mathrm{sec})$ ) that the location of the flame front moved downstream from T3 (fig. 9) to T4 (fig. 10). The flow characteristics of the mixing chamber and catalyst bed may have changed with use due to channeling of the flow, localized hot spots, or flashback, or the activity of the catalyst bed may have degraded. Figure 11 shows a transient temperature distribution for a hot fire test at nominal flow conditions. The large magnitude of T2 (and T3) for this firing, which was the first firing of a fresh catalyst bed, indicates that the flame front was located near 12 and therefore the catalyst was much more active than the firing at a mixture ratio of 1.0 in figure 10 . This emphasizes the fact that the temperature distribution depends on the nature and amount of previous testing.

A factor that had a major impact on the temperature distribution and the location of the flame front was the propellant inlet temperature. A comparison 
of figures 11 and 12 shows the effect of inlet temperature on the transient temperature distribution in the reactor. Ambient temperature propellants were used for the test firing of figure 11, while chilled hydrogen and a prechilled catalyst bed were used for the test firing of figure 12. As shown in figure 12 , when the catalyst bed was prechilled to $-97.7^{\circ} \mathrm{C}\left(-143.9^{\circ} \mathrm{F}\right)$ and chilled hydrogen was used the flame front moved downstream to $\mathrm{T} 4$ in the reactor. This was the only location in the reactor where the temperature reached a value higher than $-17.78^{\circ} \mathrm{C}\left(0^{\circ} \mathrm{F}\right)$.

Testing was next conducted to determine the overall effect of initial bed temperature on ignition of hydrogen and oxygen using She 11405 catalyst. The bed temperature was adjusted by flowing chilled hydrogen gas through the bed prior to the test firing. The chilled hydrogen gas and ambient temperature oxygen gas were then used for the test firing. An ignition boundary for the Sheil 405 catalyst was defined by varying the initial bed temperature and mixture ratio in the reactor. The results are shown in figure 13. It was observed that as temperature decreases mixture ratio must be increased to achieve ignition of the hydrogen and oxygen propellants. A model proposed by Kesten (ref. 6) suggests that for low-temperature, hydrogen-rich systems the overall reaction rate strongly depends on the concentration of oxygen and the temperature within the catalyst particle. It is suggested that catalyst activity is temporarily reduced by capillary condensation or freezing of water in the cold catalyst particles. If significant quantities of water block enough pores to isolate large segments of the porous particle from the reactants, the catalyst bed would be rendered entirely ineffective. This would explain the effects of catalyst bed temperature and mixture ratio on ignition as shown in figure 13. Ignition of hydrogen and oxygen in the catalytic igniter was demonstrated with initial Shell 405 catalyst temperatures as low as $-112.8{ }^{\circ} \mathrm{C}$ $\left(-171.1^{\circ} \mathrm{F}\right)$ and fuel inlet temperatures as low as $-165.2^{\circ} \mathrm{C}\left(-265.4^{\circ} \mathrm{F}\right)$. Ignition is possible at lower initial catalyst bed temperatures, but the resulting ignition temperature at the higher mixture ratio would be detrimental to the life of the catalyst bed.

To characterize the overall operation of the igniter, testing was conducted using downstream oxygen injection. For these cases, the total mixture ratio for the igniter was;

$$
\left(\frac{O}{F}\right)_{t}=\frac{W_{O a}+W_{O b}}{W_{f a}}
$$

where

$$
\begin{array}{ll}
(O / F)_{t} & \text { total mixture ratio } \\
W_{\text {oa }} & \text { primary oxygen mass flow rate, } \mathrm{kg} / \mathrm{sec} \\
W_{\text {ob }} & \text { secondary oxygen mass flow rate, } \mathrm{kg} / \mathrm{sec} \\
W_{f a} & \text { hydrogen mass flow rate, } \mathrm{kg} / \mathrm{sec}
\end{array}
$$

For optimum igniter operation, the total mixture ratio should be near stoichiometric in order to release the maximum amount of energy for main propellant ignition, while the reactor mixture ratio remains low to increase the ilfe of the igniter. To determine the optimum operating conditions for the 
igniter, the catalyst bed and total mixture ratios were varied, while holding the mass flow rate through the reactor constant at $0.0027 \mathrm{lb} / \mathrm{sec}(0.006$

$1 \mathrm{~b} / \mathrm{sec}$ ).

The results of this testing, plotted in figure 14, show that a boundary exists between Ignition and no ignition in the downstream chamber. Fuel rich mixtures in the downstream chamber were difficult to ignite. Ignition in the downstream chamber could not be achieved at total mixture ratios less than 5. Oxidizer rich mixtures in the downstream chamber were easily ignited, even at catalyst bed mixture ratios as low as 0.4 .

The igniter was tested without downstream injection at sea level (ambient pressure) and at space simulated conditions. The ignition characteristics in the reactor were not responsive to variations in nozzle back pressure. The flow. through the downstream injector was choked for the range of reactor flows tested. Tests were not conducted to determine the effect of nozzle back pressure on the ignition characteristics when downstream oxygen was employed.

\section{Monolithic Sponge Catalyst Tests}

Igniter tests were conducted in which a monolithic sponge catalyst replaced the Shell 405 granular catalyst. The unique feature of this monolithic catalyst was that the active catalyst material was deposited directly onto the monolithic sponge support by chemical vapor deposition without the use of a porous, high surface area washcoat. Porous washcoats are used with noble metal catalysts to increase the surface area for dispersion of the catalyst agent when the surface area of the support itself is low. However, washcoats can be life-limiting to the catalyst because their coefficient of thermal expansion or thermal conductivity may be different from that of the monolithic support or because the washcoat may not adhere well to the monolithic support. In addition, sponge monoliths are difficult to washcoat because the washcoat tends to deposit in and $c \log$ the pores of the sponge.

The monolithic sponge catalyst was not successful for ignition of the gaseous hydrogen and oxygen propellant combination. At nominal igniter operating conditions, the monolithic catalyst bed was only able to elevate the temperature in the reactor slightly. This inability to ignite the propellants was due to the low available active surface area of the monolith. The porous Shell 405 granular catalyst possesses a much larger active surface area per unit volume than the monolithic sponge catalyst, which had only its geometric surface area available for catalyst dispersion.

The performance of the monolithic sponge catalyst at nominal igniter operating conditions is shown in figures 15 and 16 . Figure 15 shows the effect of mass flow rate on exit temperature for a mixture ratio of 1.0 . It was observed that reducing the mass flow rate and, hence, the velocity of gases through the monolithic sponge catalyst bed increased the exit temperature. Figure 16 shows the effect of mixture ratio on the exit temperature for a mass flow rate of $0.0018 \mathrm{~kg} / \mathrm{sec}(0.004 \mathrm{lb} / \mathrm{sec})$. As expected, the exit temperature increased with increasing mixture ratio. Ignition could not be achieved for mixture ratios below 3.0 in the monolithic catalyst bed. At a mixture ratio of 3.0 , ignition was achieved which destroyed the monolith due to the extreme temperature. The poor performance of the monolithic sponge catalyst in these tests can be attributed to two factors. The low active surface area of the catalyst prevented ignition at a nominal reactor mixture ratio of 1.0 , and the structural 
durablility of the catalyst was inadequate due to the use of the carbon substrate. Upon ignition, the monolithic sponge catalyst was immediately destroyed.

\section{Igniter Performance}

In order to obtain a measure of the overall performance of the catalytic igniter using Shell 405 catalyst, the $C^{*}$ efficiency was calculated for the runs with downstream oxygen injection. The following relation was used to estimate $C^{*}$ efficiency.

$$
C_{\text {eff }}^{*}=\frac{P_{c} A_{t}}{W_{\text {tot }}} C_{\text {th }}^{C^{*}}(100)
$$

where

$C_{\text {eff }}^{*}$ experimental $C^{*}$ efficiency of the igniter
$P_{C}$ pressure in the downstream chamber, $\mathrm{MN} / \mathrm{m}^{2}$
$A_{t} \quad$ cross-sectional throat area, $\mathrm{m}^{2}$
$W_{t o t}$ total mass flow rate, $W_{o a}+W_{f a}+W_{o b}, \mathrm{~kg} / \mathrm{sec}$
$C_{t h}^{*}$ theoretical characteristic velocity for $i g n i t e r, \mathrm{~m} / \mathrm{sec}$

Figure 17 shows the variation in $C^{*}$ efficiency with the total mixture ratio of the catalytic igniter. The $C^{*}$ efficiency reaches a peak value of 79.2 percent at the stoichiometric mixture ratio for hydrogen/oxygen, 8.0. The low values of $C^{*}$ efficiency can be attributed primarily to thermal losses and inefficient mixing of propellants in the downstream chamber.

\section{Pulse Mode Life Tests}

Testing was also conducted (without downstream injection) to determine the life of the Shell 405 catalyst bed. The testing consisted of 2-sec pulses followed by a 15-sec cooldown period. After the first 1100 pulses, an attempt was made to shorten the cooldown period between runs by convectively cooling the exterior surface of the reactor with water, as opposed to the normal cooldown by forced convection of air over the exterior surface of the igniter. The decreased time between runs was not sufficient to allow the catalyst bed to be purged of all the reacted gases between runs, and flashback occurred. This flashback altered the flow characteristics in the mixing chamber, which in turn altered the ignition characteristics of the igniter. Because of the adverse effects it caused, the water cooling was stopped after 10 pulses. Testing then resumed as before, with the catalyst bed sustaining ignition for a total of 1980 pulses. 
Figures 18 and 19 show the characteristics of the igniter during the pulse-mode life tests. Only data from the first 1100 pulses are reported here because of the change in performance after water cooling was attempted. Figure 18 shows the variation in pressure drop across the catalyst bed and downstream injector as the number of pulses increase. The pressure-drop increase throughout the testing can be attributed to degradation of the mixing chamber material and catalyst bed and to small catalyst particles clogging the downstream injector orifices. Figure 19 shows the variation in the temperature distribution in the bed as the number of pulses increase. The large values of $T 2$ and T3 indicate that after approximately 500 pulses, the temperature distribution reached a steady operating limit, after which T3 and T4 decreased only slightly as the number of pulses increased.

\section{CONCLUDING REMARKS}

An experimental program was conducted at NASA Lewis to investigate the catalytic ignition of gaseous hydrogen and oxygen propellants. The objectives of the program were to establish design guidelines for catalytic igniters, develop an experimental data base for catalytic ignition of hydrogen and oxygen propellants, and demonstrate the life and reliability of the catalytic igniter for rocket propulsion systems. Contributions to an existing experimental data base for catalytic ignition of hydrogen and oxygen propellants were made in the areas of low-temperature ignition, monolithic catalyst beds, and propellant injection and mixing techniques.

The feasibility of catalytic ignition for reusable propulsion systems using hydrogen and oxygen propellants was demonstrated with a cyclic life test of nearly 2000 consecutive $2-\sec$ pulses at nominal operating conditions, with no maintenance to the igniter required. In other tests mixture ratio, mass flow rate, propellant temperature, and back pressure were varied parametrically to establish the operational limits at which a catalytic igniter using Shell 405 granular catalyst can be reliably operated. The results of these tests show that the gaseous hydrogen and oxygen propellant combination can be ignited catalytically over a wide range of operating conditions, but the igniter must be operated within these established conditions to ensure reliable ignition for an extended period of time. Ignition was demonstrated with initial shell 405 catalyst bed temperatures as low as $-112.8^{\circ} \mathrm{C}\left(-171.1^{\circ} \mathrm{F}\right)$ and fuel inlet temperatures as low as $-165.2{ }^{\circ} \mathrm{C}\left(-265.4^{\circ} \mathrm{F}\right)$. The ignition temperature threshold decreases as the mixture ratio in the catalyst bed is increased and ignition is possible at lower initial catalyst bed temperatures, but the resulting temperature at the higher mixture ratio would be detrimental to the life of the catalyst bed.

Tests were also conducted using a monolithic sponge catalyst which consisted of a carbon sponge substrate coated with rhenium to give it structural integrity and iridium as the catalyst agent. Although this type of monolithic catalyst did not perform well because its active surface area and structural durability were inadequate, it is belleved that other types of monolithic catalysts hold promise for improved life and reliability of catalytic igniters because of their lower pressure drop, improved attrition resistance, and greater design flexibility compared to granular catalysts. 


\section{REFERENCES}

1. Pollard, F.B.; and Arnold, J.H., Aerospace Ordnance Handbook, Prentice-Hall Inc., Englewood Cliffs, NJ, 1966, Chapter 3, .

2. Roberts, R.W., Burge, H.L., and Ladacki, M., "Investigation of Catalytic Ignition of Oxygen/Hydrogen Systems," R-6303, Rockwell International Corp., Canoga Park, CA, Dec. 1965, NASA CR-54657.

3. Russi, M.J., "A Survey of Monopropellant Hydrazine Thruster Technology," AIAA Paper 73-1263, Nov. 1973.

4. Johnson, R.J., "Hydrogen-Oxygen Catalytic Ignition and Thruster Investigation; Volume I - Catalytic Ignition and Low Pressure Thruster Evaluations," TRW-14549-6001-R0-00-VOL-1, TRW Systems Group, Redondo Beach, CA, Nov. 1972, NASA CR-120869.

5. "Monolithic Catalyst Beds for Hydrazine Reactors," REPT-73-R-360, Rocket Research Corp., Redmond, WA, May 1973, NASA CR-132983.

6. Kesten, A.S., and Sangiovanni, J.J., "Transient Model of A Hydrogen/Oxygen Reactor," UARL-K910962-12, United Aircraft Corp., East Hartford, CT, Feb. 1971, NASA CR-120799.

TABLE I. - SHELL 405 CATALYST SPECIFICATIONS

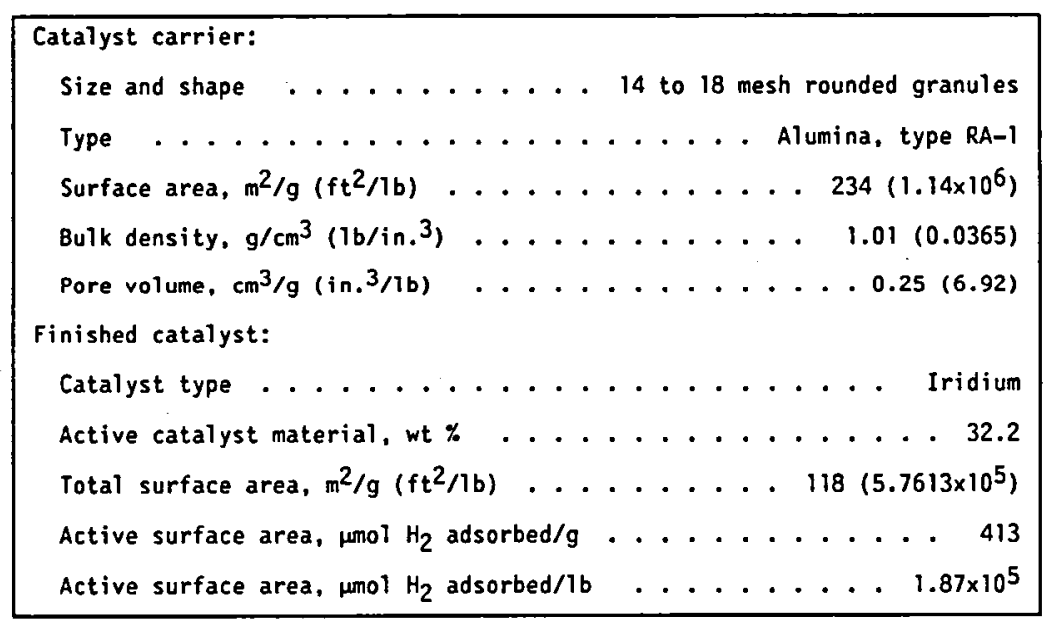

TABLE II. - MONOLITHIC SPONGE CATALYST CHARACTERISTICS

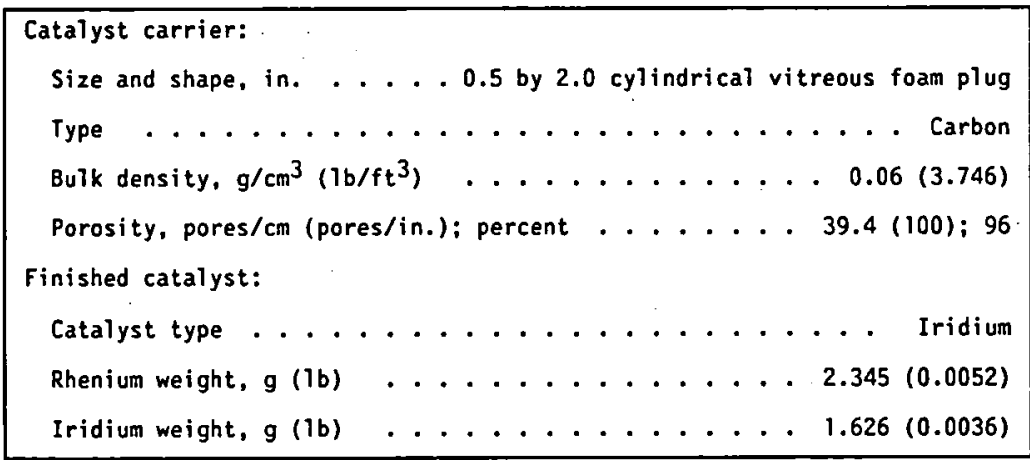




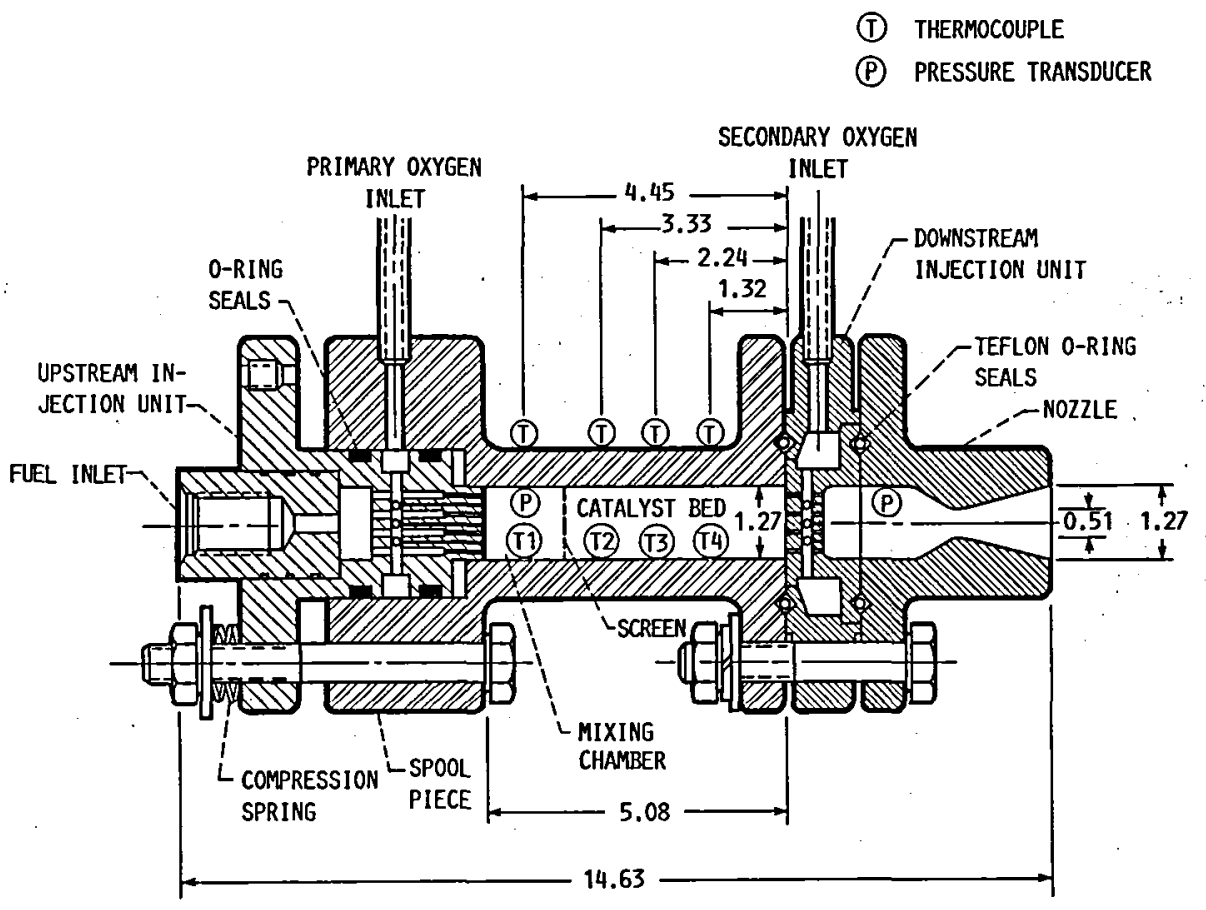

FIGURE 1. - SCHEMATIC OF CATALYTIC IGNITER HARDWARE. [ALL DIMENSIONS IN CENTIMETERS.]
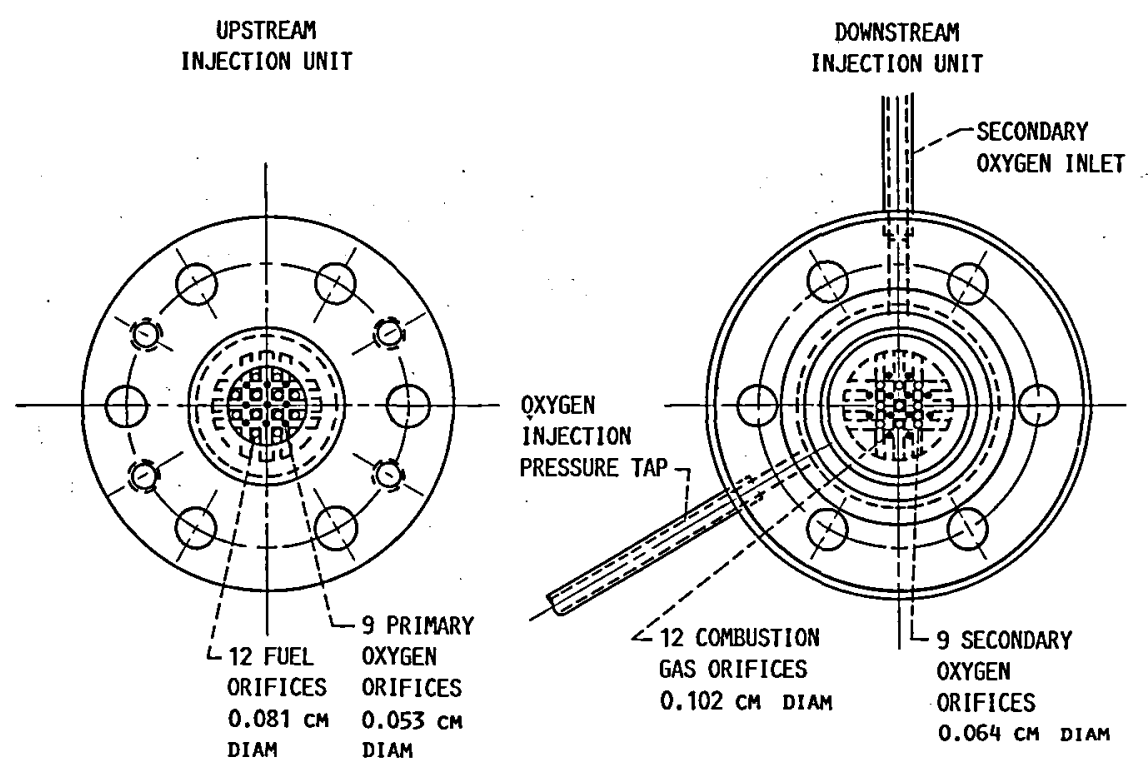

FIGURE 2. - SCHEMATIC OF INJECTOR UNITS. 


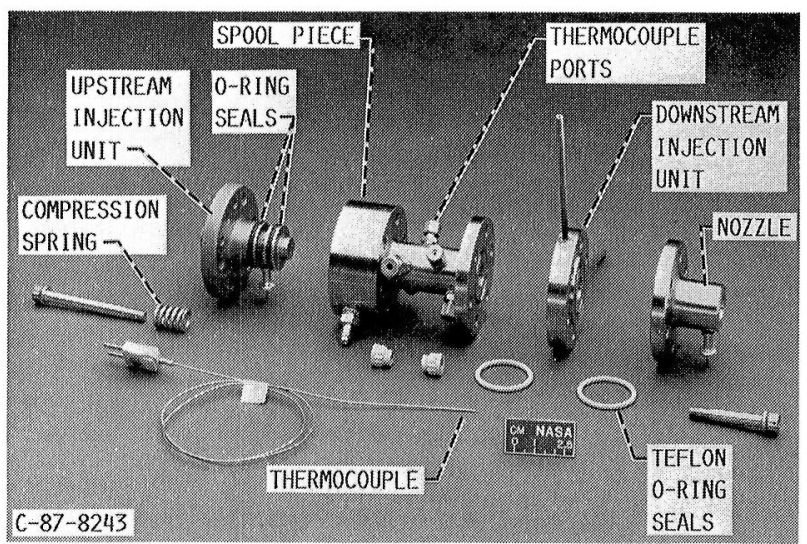

FIGURE 3. - EXPLODED VIEW OF CATALYTIC IGNITER HARDWARE.

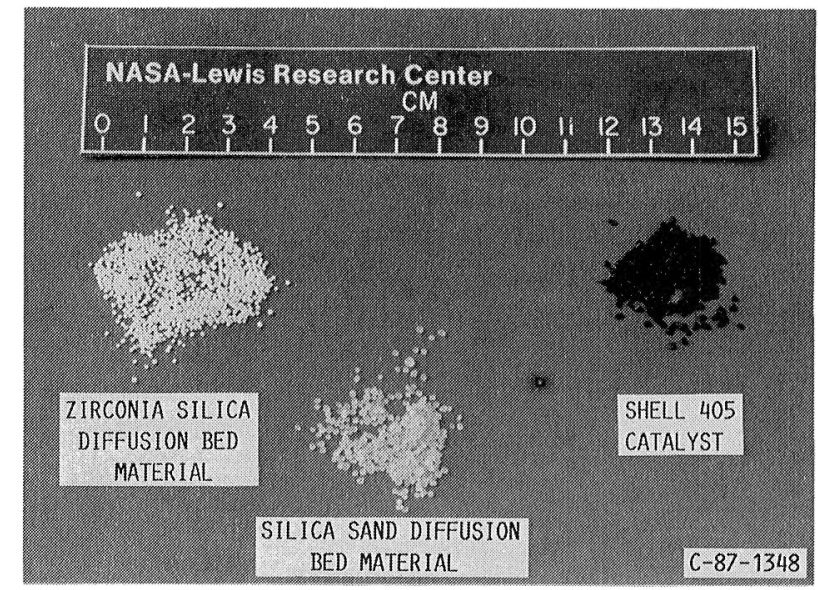

FIGURE 4. - CATALYST AND DIFFUSION BED MATERIAL.

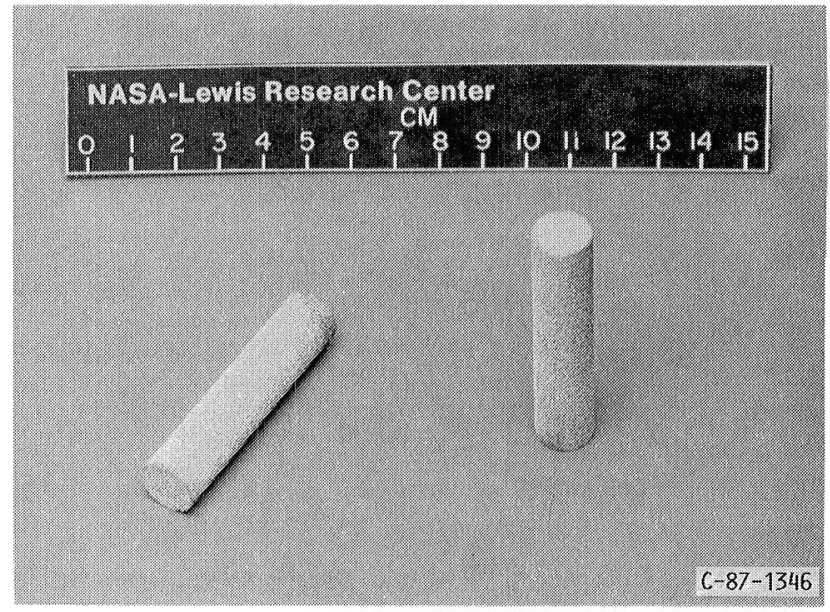

FIGURE 5. - MONOLITHIC SPONGE CATALYST.

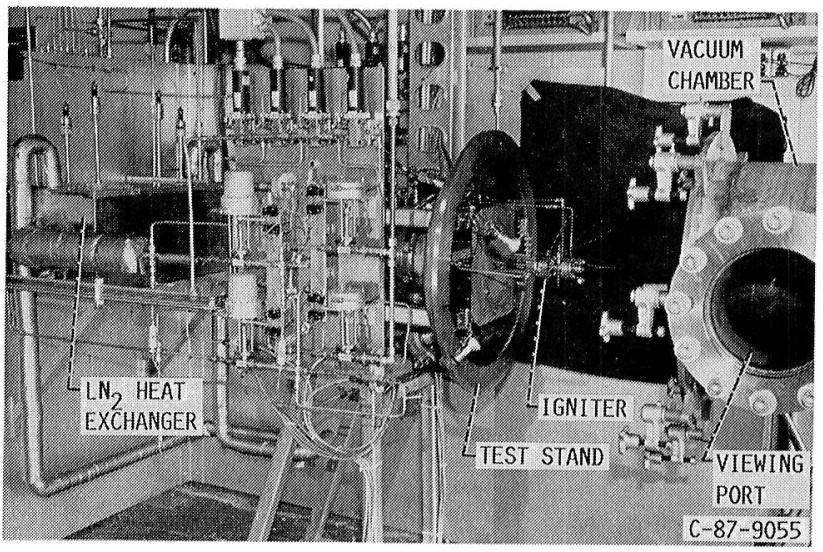

FIGURE 6. - TEST STAND. 


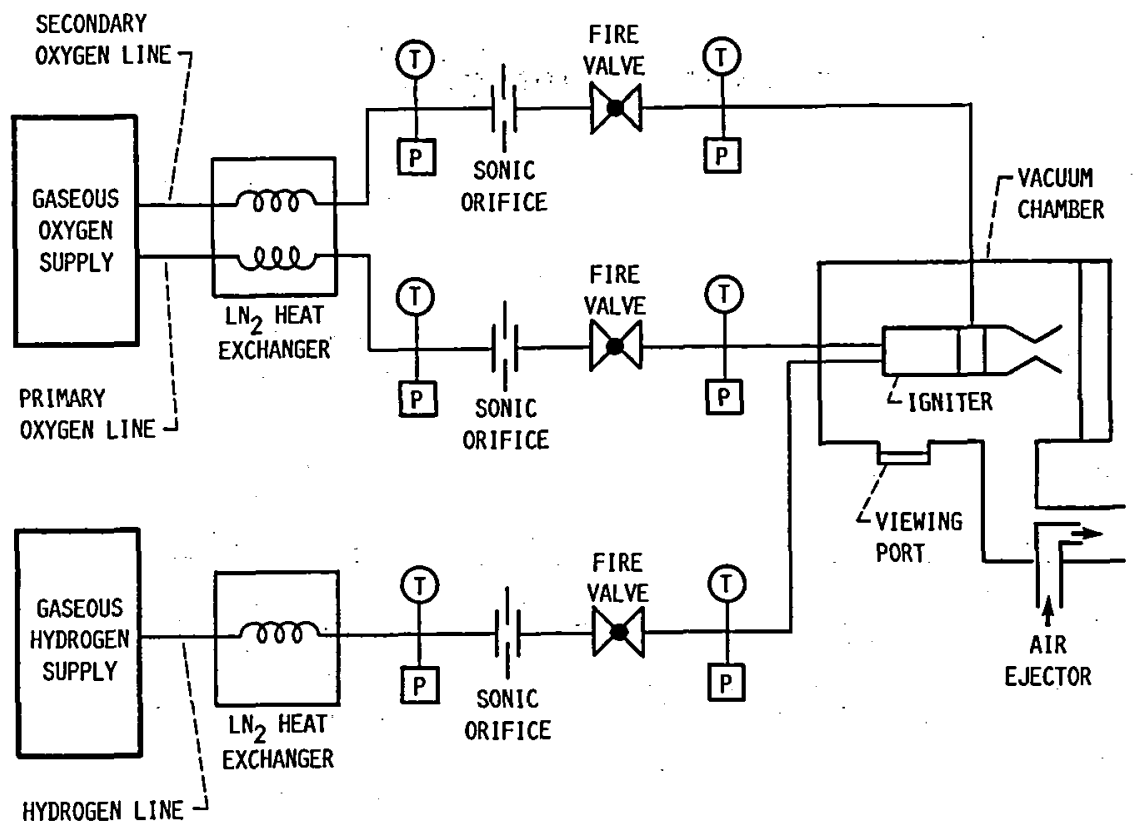

FIGURE 7. - PROPELLANT FEED SYSTEM SCHEMATIC.

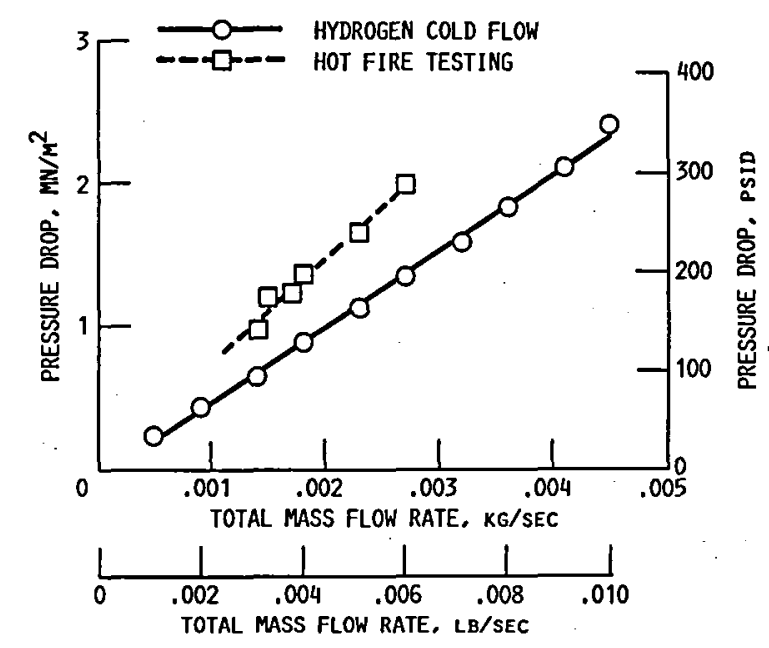

FIGURE 8. - EFFECT OF MASS FLOW RATE ON REACTOR PRESSURE DROP. [MIXTURE RATIO $=1.0: 3 \mathrm{SEC}$ RUN DURATION FOR HOT FIRE TESTS.]
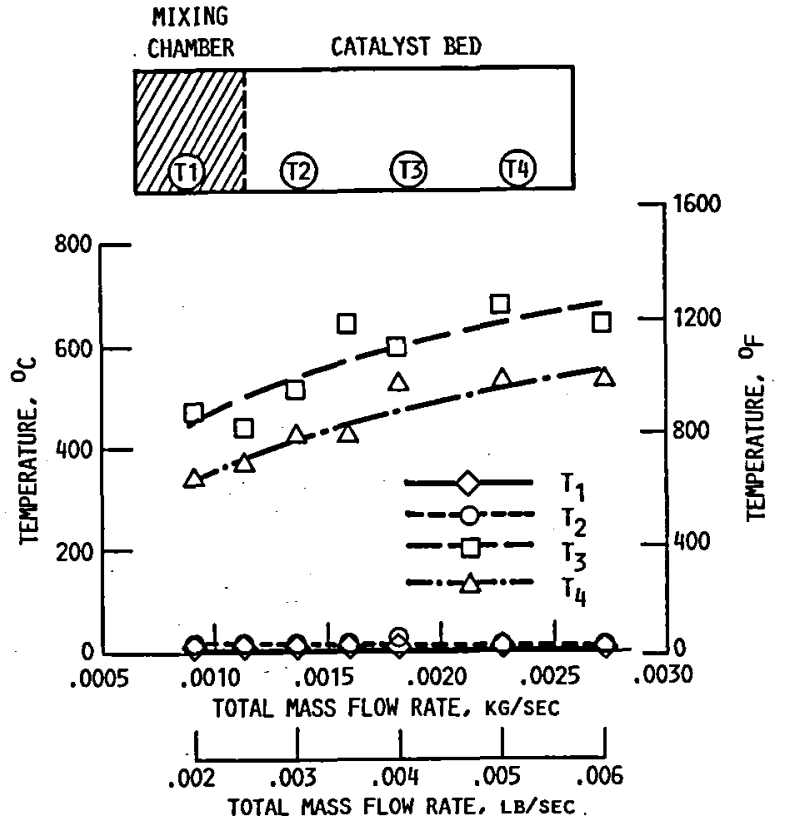

FIGURE 9. - EFFECT OF MASS FLOW RATE ON REACTOR TEMPERATURE DISTRIBUTION. [MIXTURE RATIO = 1.0; 3 SEC RUN DURATION.] 

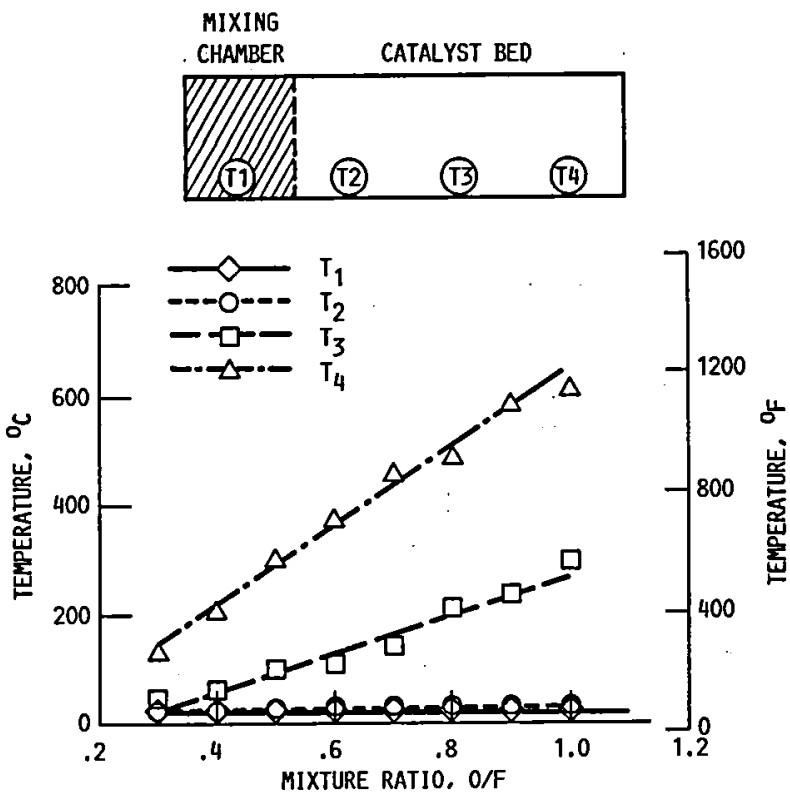

FIGURE 10. - EFFECT OF MIXTURE RATIO ON REACTOR TEMPERATURE DISTRIBUTION. [TOTAL MASS FLOW RATE $=0.0018 \mathrm{KG} / \mathrm{SEC}(0.004 \mathrm{LB} / \mathrm{SEC}): 3 \mathrm{SEC}$ RUN DURATION.]
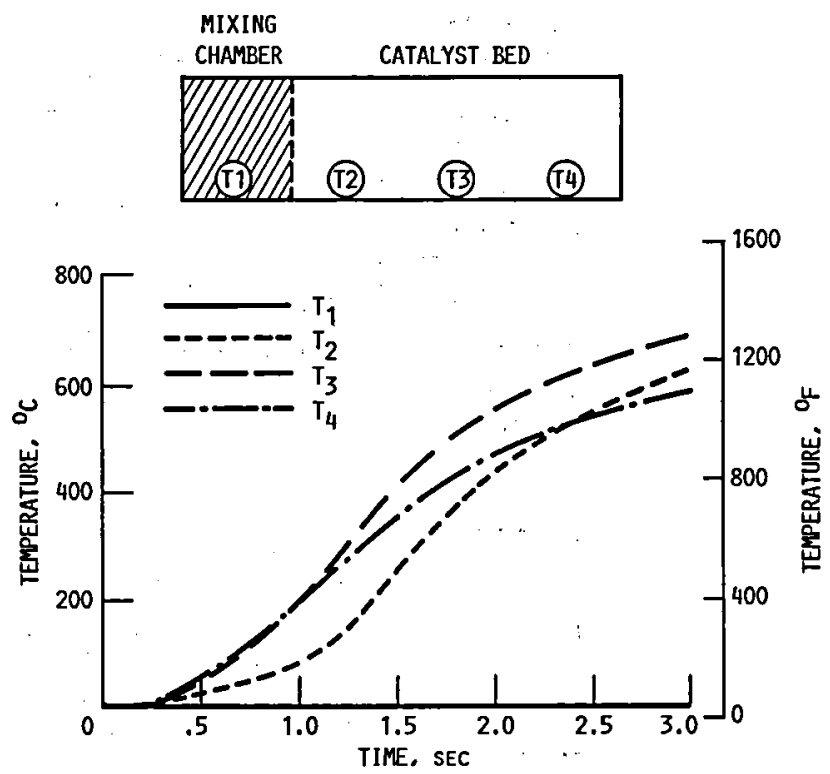

FIGURE 11. - REACTOR TEMPERATURE TRANSIENT FOR NOM-

INAL FLOW CONDITIONS. [TOTAL MASS FLOW RATE $=$

$0.0018 \mathrm{KG} / \mathrm{SEC}(0.004 \mathrm{LB} / \mathrm{SEC}) ;$ MIXTURE RATIO $=1.0$ 3 SEC RUN DURATION.]
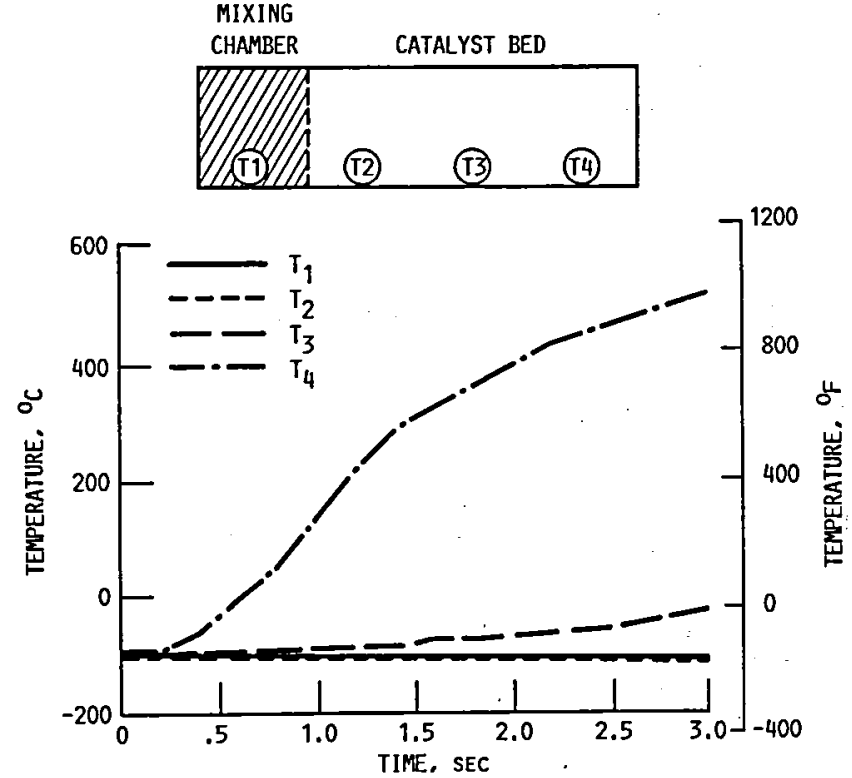

FIGURE 12. - EFFECT OF INLET TEMPERTURE ON REACTOR TEMPERATURE TRANSIENT. [TOTAL MASS FLOW RATE = $0.0018 \mathrm{kG} / \mathrm{SEC}(0.004 \mathrm{LB} / \mathrm{SEC}):$ MIXTURE RATIO $=1.0$; 3 SEC RUN DURATION.]

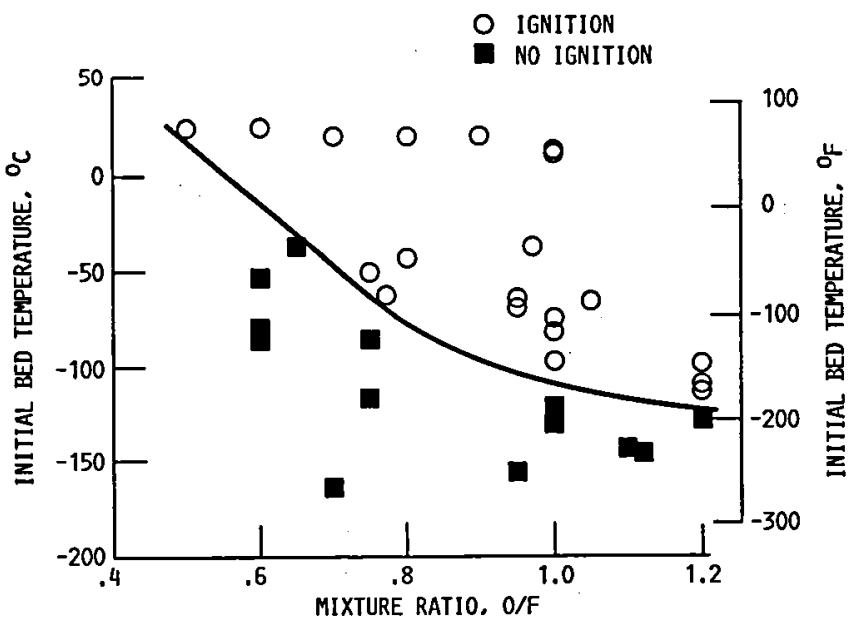

FIGURE 13. - EFFECT OF INITIAL BED TEMPERATURE AND MIXTURE RATIO ON IGNITION. [TOTAL MASS FLOW RATE $=0.0018 \mathrm{KG} / \mathrm{SEC}(0.004 \mathrm{LB} / \mathrm{SEC}): 3$ SEC RUN DURATION.] 


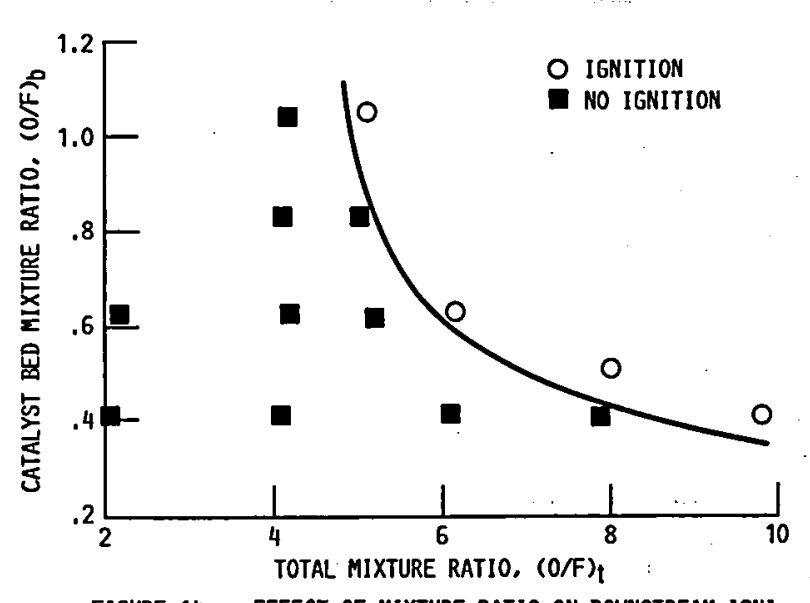

FIGURE 14. - EFFECT OF MIXTURE RATIO ON DOWNSTREAM IGNITION. [TOTAL MASS FLOW RATE $=0.0027 \mathrm{kG} / \mathrm{SEC}(0.006$ LB/SEC): 2 SEC RUN DURATION.]

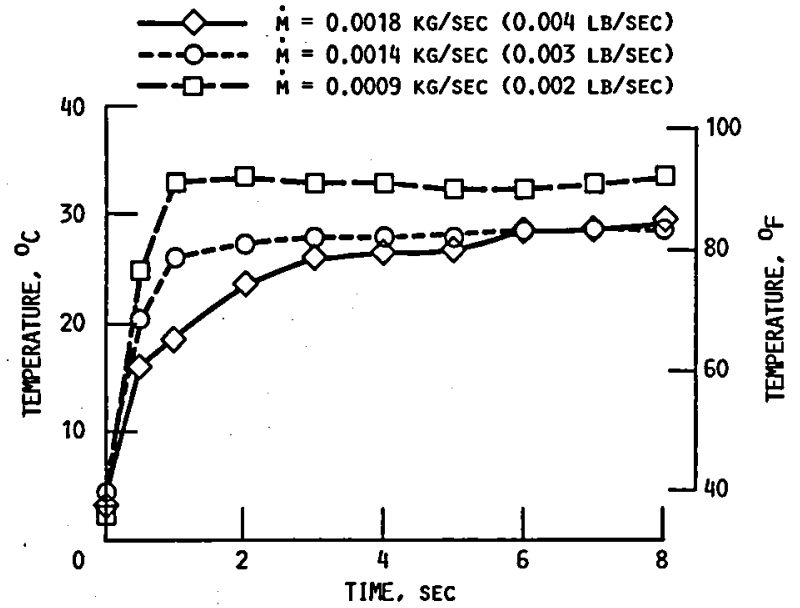

FIGURE 15. - EFFECT OF MASS FLOW RATE ON REACTOR TEMPERATURE FOR THE MONOLITHIC SPONGE CATALYST. [MIXTURE RATIO $=1.0$.

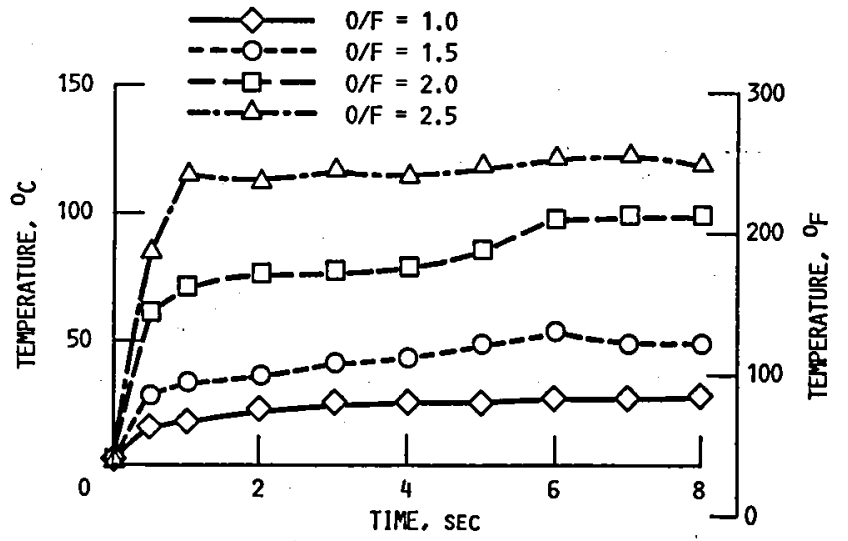

FIGURE 16. - EFFECT OF MIXTURE RATIO ON REACTOR TEMPERATURE FOR THE MONOLITHIC SPONGE CATALYST. [TOTAL MASS FLOW RATE $=0.0018 \mathrm{~kg} / \mathrm{sEC}(0.004$ [B/SEC).]

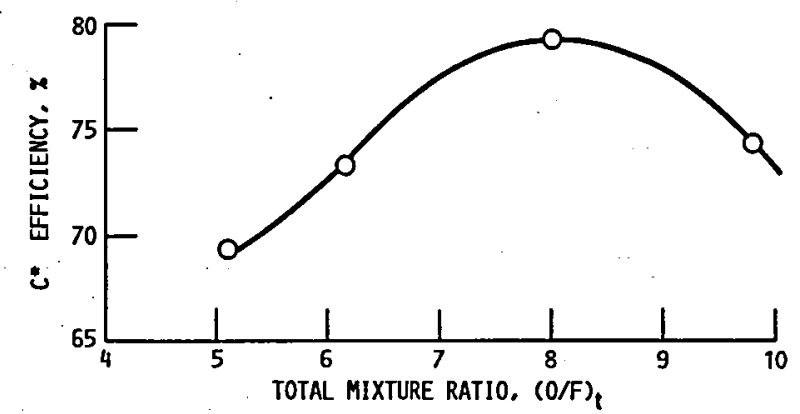

FIGURE 17. - EFFECT OF TOTAL MIXTURE RATIO ON IGNITER C* EFFICIENCY, [REACTOR MASS FLOW RATE $=0.0027$ $\mathrm{KG} / \mathrm{SEC}(0.006$ LB/SEC); 2 SEC RUN DURATION.] 


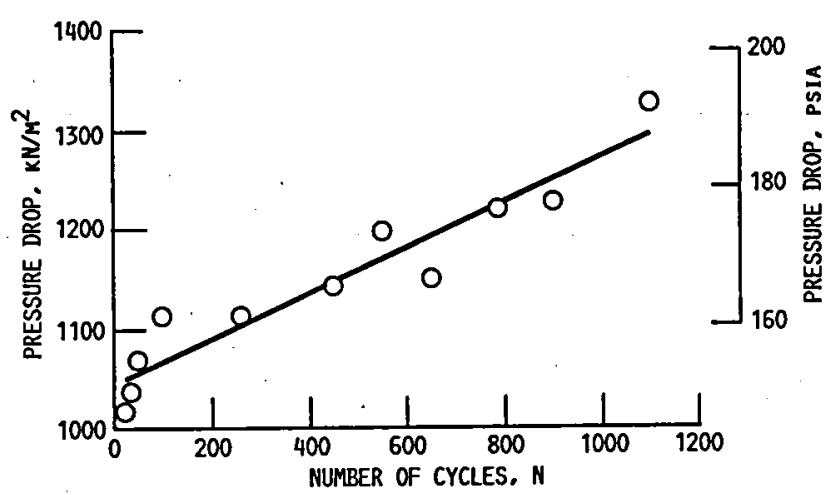

FIGURE 18. - VARIATION OF REACTOR PRESSURE DROP FOR CYCLIC LIFE TESTING. [TOTAL MASS FLOW RATE = $0.0018 \mathrm{kG} / \mathrm{SEC}(0.004 \mathrm{LB} / \mathrm{SEC}):$ MIXTURE RATIO $=1.0$; 2 SEC RUN DURATION.]

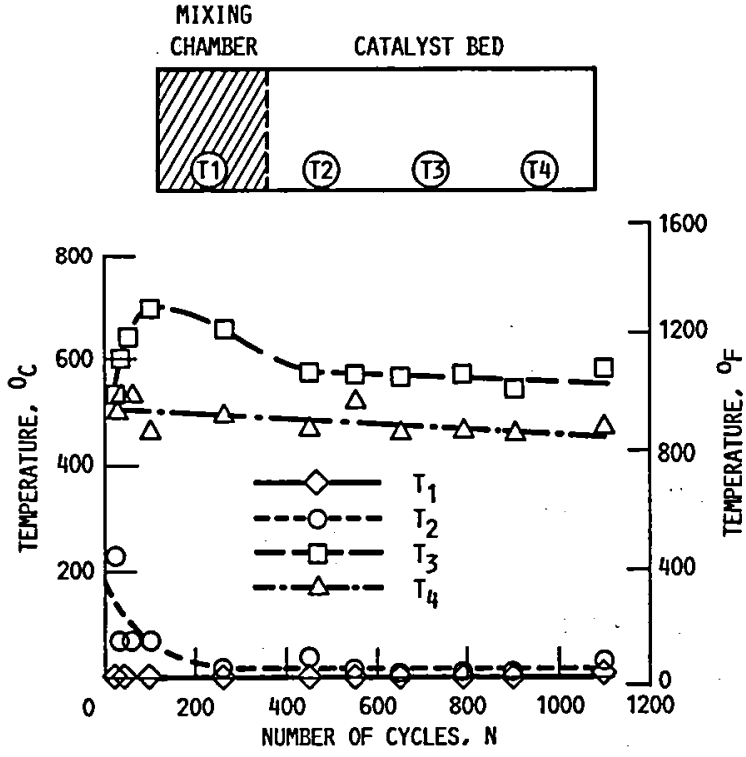

FIGURE 19. - VARIATION OF REACTOR TEMPERATURE DISTRIBUTION FOR CYCLIC LIFE TESTING. [TOTAL MASS FLOW RATE $=0.0018 \mathrm{KG} / \mathrm{SEC}(0.004 \mathrm{LB} / \mathrm{SEC})$; MIXTURE RATIO $=1.0: 2$ SEC RUN DURATION.] 


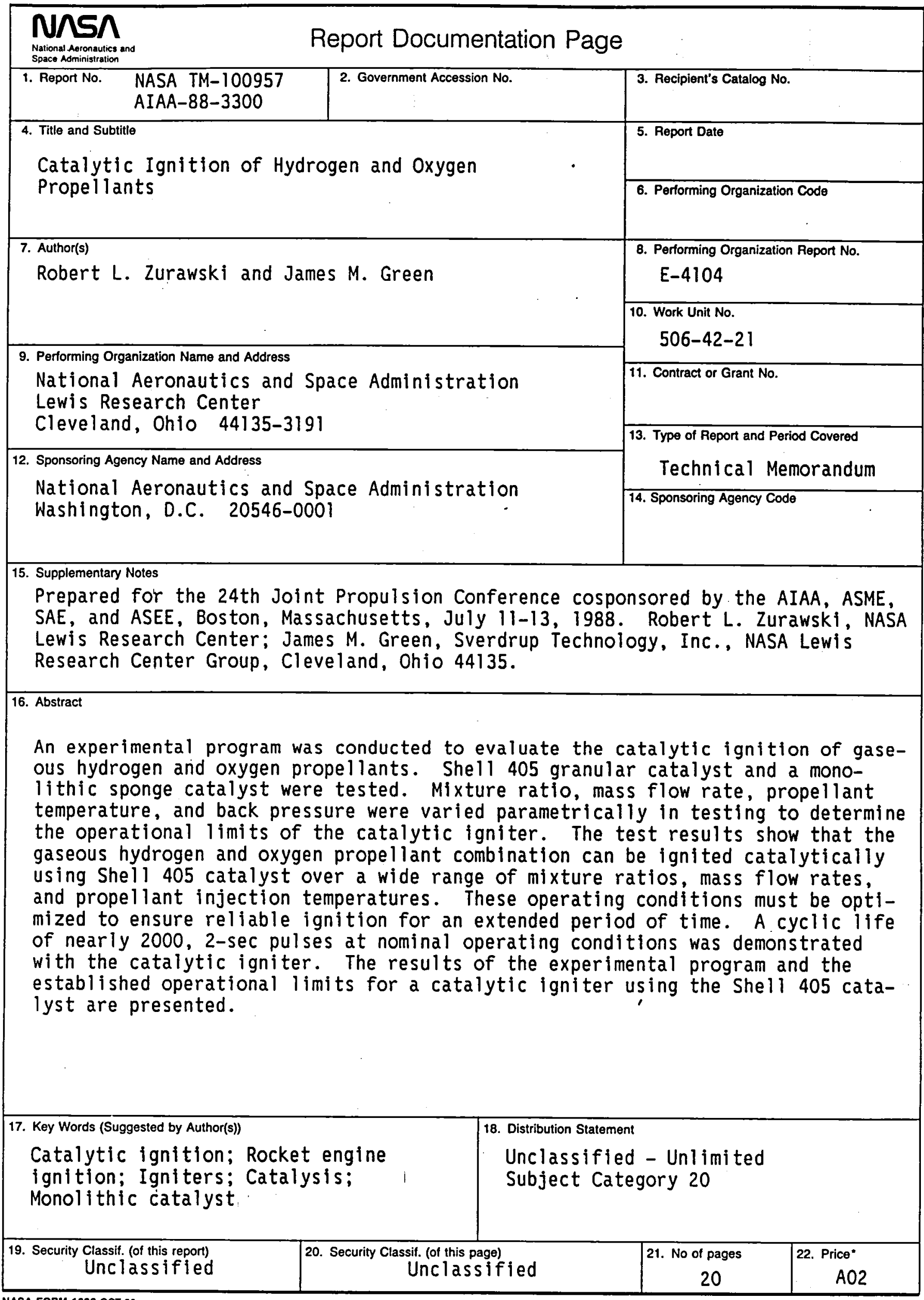


National Aeronautics and Space Administration

Lewis Research Center Cleveland, Ohio 44135

Otflcial Business

Penalty for Private Use $\$ 300$
FOURTH CLASS MAIL

\section{ADDRESS CORRECTION REQUESTED}

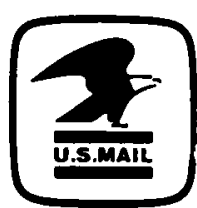

Postage and Fees Pard National Aeronautics and Space Administration NASA 451 